\title{
Burnout as Alienation in the Counselling Field: The Descent from Homo-Faber to Homo-Economous
}

\author{
Tony Carton \\ Wellington Institute of Technology, Auckland, New Zealand \\ Email: tony.carton@weltec.ac.nz
}

Received 22 February 2016; accepted 5 April 2016; published 8 April 2016

Copyright () 2016 by author and Scientific Research Publishing Inc.

This work is licensed under the Creative Commons Attribution International License (CC BY). http://creativecommons.org/licenses/by/4.0/

(c) (1) Open Access

\section{Abstract}

The concepts burnout and alienation are routinely connected in a linear unproblematic trajectory (Tomei et al., 2011) perpetuating more of an ideological conflation than providing any insight into either concept. This is not due to the selection of shoddy analytic categories but to structural determinants of thinking, more systemically interesting than the entities themselves. The author attempts to problematize, politicise and polemicize the insipid commonsense understandings of these classifications endemic in the counselling/addictions field. An informal discourse analysis was conducted on an aggregate example based on observation over several years in teaching professional practice. He concludes that the reported trajectory from alienation to burnout is more a narrative around changing ideology diffusion than a robust appraisal of social science. Furthermore, the concept of burnout serves to perpetuate, worsen and naturalise the problems it claims to remedy by a facilitation of spiritualising acts of passivity. An appreciation of alienation on the other hand enables awareness of the unnaturalness of current neo-liberal social structures. The author concludes that the quazi-religious mantra of burnout invites the reader into a regime of self-care/self-blame contradictions and proves its effectiveness not by applicability but repetition. By continued use of the concept we reify the myth of burnout and grant it credence. The author also describes how clinicians enact their own informal and invisible means of resistance to power in the workplace where solidarity is enacted through humour and humanity.

\section{Keywords}

Alienation, Burnout, Homo-Faber, Homo-Economous, Marx, Materialism

\section{Introduction}

It is routine when reviewing the issue of burnout to include a passing reference to the subject of alienation. Of- 
ten alienation is referred to in humanistic almost mystical terms such as "powerlessness, meaninglessness, normlessness, isolation, and self-estrangement" (Seeman, 1959) befitting a quazi-spiritual turn endemic in the counselling field. The appropriation of the term alienation has also accommodated a de-politicisation of the term. However, this tells more about the ideological positioning of the writer than any insight into the concept. The elegant linearity of a literature review obscures the fact that these two concepts are at polar opposites from each other. Moreover, the differences are profound in that they address a transition in the understanding of the function of humanity from Homo-Faber to Homo-Economous. That is, from a species that exists to labour for the material and spiritual reproduction of human-kind to one who exists to live an economically obsessive life wedged between contradictions of compulsive cost saving and unrestrained consumerism.

\section{Alienation in the Counselling Field}

Counsellors assent to a Hegelian assumption based on a stable progress towards an ideal, often encapsulated in the current language of counselling referring to growth, change and the achievement of goals. This is an ideology that speaks to a duality between ideal/material and an ineluctable dialectic towards the ideal. As such it manifests an aura of vacuous spirituality which also currently privileges ideological templates around positivity and resilience. Marx in his earlier career was a Hegelian devotee but he later inverted the whole Hegelian concept developing the concept of dialectic materialism. He surmised that the way we live is not so much a by-product of our ideals, but our ideals are a by-product of how we live. It is in the nature of humanity to reproduce for the material, thereby spiritual needs of the species (Marx, 2012). If we live in a society based on inequality our ideals will reflect this. Unless that is if we can become aware of our false consciousness, that is when our beliefs and actions do not serve the needs of our fellow humans, but the needs of an exploitative class. However due to the counselling professions veneration of the individual, any discussion around Marx in the field is akin to heresy. However, the field is obsessed by the theme of false consciousness, not least through Freudian theory.

\section{Methodology}

The methodology was a hybrid of an informal discourse analysis and observations of an aggregate group taken over several years in first, second and third year degree of addiction practicum classes. It was nearing the end of the term and each student was asked to describe a particularly challenging case encountered in their placement or place of work. The class had gone through the various group stages (Clarkson, 1991) and now were well into the performing mode. At this late stage of the student's development there was a reasonably sophisticated level of interaction. As a result, the peer-supervision that evolved was incisive. The tutor was able to relax somewhat and observe the process. The group demonstrated that that they had integrated many of the concepts that tertiary education in the Addiction field instils into the new professional. There was an adequate mixture of content and process, the details of a particular event would be described and the process included the listeners observing and feeding back.

The narrative is divided into three parts, the beginning, the middle and the end.

\subsection{Part 1: Beginning (Active)}

Each person provided background information on where they were working/on placement, some information on the service given before introducing the client in the case study. The client had issues such as family violence, drink driving or drug offences. The students had been encouraged to provide a preamble before each presentation around the idea of ethical itches that may humanise the challenges involved in the cases.

At the beginning they were asked to describe the precipitating factors, e.g. why the client presented. The drama in the discourse seemed appropriate, inferring this incident was part of a long impacted narrative with routines, resolutions (or pseudo resolutions) and climaxes. By doing this they were able to describe both the usual and exceptional in so doing they located the power of a homeostasis of pathological normality that perpetuated the abuse. It was the role of the clinician to enable a subversion of this. In each case there was the "primary stressor" (Deutsch, 1984). This was usually the non-compliant or violent client. During this time, it was noticeable that the vocabulary was in active terms, at times almost animated.

1) "He belted her the night before." 
2) "She went out and got shit faced."

3) "He relapsed once again."

4) (Quoting a client) "the fucking cop saw me wavering over the road."

5) "I went for a home visit and after a while I noticed her black eye. Jack had got wasted last night and belted her. He was there too... seemed apologetic... as he stood over me."

Each statement enlisted a response, from the class, professional yet supportive, often suggesting the use of counselling techniques including Client Centred Practice, Cognitive Behavioural Practice or Motivational Interviewing as well as feedback on risk factors and likely support services in the community.

Although the language employed the active tense, occasioning at times swear words there was an overall sense of the appropriateness of the language. There did not appear to be glances of approval towards the lecturer for permission as they were attending to the primary stressors and as such using appropriate coal face language. Moreover, several students who, due to religious/ethical beliefs did not use swear words, nodded approval as an act of solidarity for their colleagues. Verbs were utilized prominently; someone had done something, or had something done to them. By using this language there was an overwhelming sense of agency, both with the clinician and the client. The linguistic imagery was real, vivid and present.

However, towards the end of the case study there was a paradoxical by-line to the effect that structural issues within the service were at work in the case as a major impediment. Noticeably this was addressed often in the passive impersonal voice having the resonance and power of afterthought and resolution. These issues are often relegated under the peripheral descriptor "secondary issues". However, the paradox is that the primary cause of burnout is discursively relegated to secondary status is not lost on most sophisticated clinicians who understand the depoliticising impact of the language game.

\subsection{Part 2: Middle (Passive)}

It was noticeable that in every case structural issues (secondary stressors) were cited as the most difficult aspects of the work yet paradoxically these were relegated to by-product status. The vocabulary was accomplished by using the passive tense and drawing on professionalised, passive and formal styles of language. These issues were often referred to towards the end of the presentation as part of the summing up such as.

We do not have the funding available.

The budget has been overspent in the area of...

We do not have the staff available to have two people do home visits.

The lack of agency, the use of the possessive pronoun "we" and the passive tenor of the language spoke to an invisible, nameless and relentless power that served to alienate them from client, peers and themselves. At times there was a visitation (albeit tokenistic) to self-blaming under the remit of overstepping of professional boundaries. There were comments such as, "We know you should/shouldn't... but”, the conjunction but hanging like an unanswered lamentation.

When burnout was discussed it was often in the third person or in the past or with confessional overtones and a reported narrative that it had been a useful conceptual tool.

\subsection{Part 3: The Conclusion (Resolution Burnout Theory as Placebo)}

At this stage it is common for counsellors to access the discourse of burnout and indulge in a quasi-spiritual practice which effectively supports Marx's contention that religion, or in this case it's "degutted" version (Eagleton, 2014) spirituality which acts as the "opium of the masses" (Marx, 1990). At one stroke it attends to the issues individualises them and thereby intensifies them. Paradoxically the practice is effective in that students seem to feel better, probably because this is a requirement of a curriculum in the profession. It consists often of a recital of suggested remedies (see Appendix).

What was noticed was that it produced a quiet resolution, a metaphysics rendered effective by repetition rather than applicability. Myths as Armstrong (1994) has argued may or may not be true but they continue to happen. The practice worked by enabling an alienating solidarity. Everyone knew the suggestions were unworkable, but everyone knew that everyone knew. In this way there was a parallel-process (Morrissey \& Tribe, 2001) in that the team mirrored the pseudo-resolution, the impacted unworkability, often manifested in client 
cases. For many sophisticated addiction clinicians this if often made understandable by the concept of powerlessness. What is often not understood is that the issue is less to do with powerless but more to do with the ubiquity of power.

There was also the profound recognition that middle management were also powerless in remedying many situations. This issue was frequently addressed through the use of verbal softeners, but there was a realisation, indicated by subtle body language that there were limits of critique.

\section{Informal Modes of Resistance}

Currently unspiritualised in most organisations, probably for good reasons, are the soft guerrilla tactics indulged in by many employees. These are utilised when authorised means of resistance and critical thought are atrophied. These are as old as time, require skill, planning and an insight into human foibles. Inevitably they are facilitated through humour and solidarity, based on the recognition that many problems in the workplace are often insoluble. Indeed, the recommendations around resolving burnout (see Appendix) acted to confirm this, thereby adding to the humour and solidarity.

Noticeably though attending to the list did provide an aura of a genuinely effective exercise as most participants were familiar with it or similar lists. Paradoxically what also increased the solidarity was an accomplished collective narrative over the impracticality of the suggestions. This was accomplished by a degree of humour which added to the group camaraderie through a sophisticated irony. Humour, almost by definition is an intensely human, effective and almost holy device in enabling resistance. Dogs as far as we are aware do not make sarcastic utterances about their masters.

Some comments can be seen Appendix.

There was also a generalised comment that it would be beneficial to translate the list into Latin or Greek in order to add incomprehensibility to impracticality while enhancing its spiritual aura.

In a generalised discussion students often categorised their particular favourite varieties of humour, these included.

\subsection{Black Humour}

This is often seen as a mode of relief from the stress of client work working on a cathartic assumption around vicarious trauma. However black humour is often used as a productive strategy to enforce solidarity and a boundary marker between those who are in, and those who are out. Often it works to invert the hierarchy, the professional roles of those of higher status being ridiculed. This inverts the common sense understanding that black humour is targeted at the client, as the humour is directed at the system.

\subsection{Theoretical Insights}

Counsellors in the addiction often make sense of situations with familiarity of an appropriate theoretical base often grounded in personal experience. They have a sophisticated understanding of systems and the roles of various members that populate a system. They have developed a subtle understanding of the nexus of power and the pathological and enabling reactions to it. Therapy involves the subversion of these.

Often this will involve the ridiculing of the team family hero, the prima donna, incapable of wrong doing or making mistakes. Their alter ego the family scapegoat incapable of doing the right thing but with an uncanny insight into systemic absurdity.

The system under this theory is frozen and impacted. Žižek (2014) made the point around the double negation around systems. Members know they are not allowed to talk about certain facts, but they also know we are not allowed to talk about the fact that they are not allowed to talk about them.

\subsection{Dark Sarcasm in the Classroom}

Counselling fundamentally involves the manipulation of language. Counsellors develop an awareness of overtones, undertones, inferences, the unsaid obfuscation within restricted language. Often in a situation where people feel powerless words will emerge to offer ways of resistance, "Power and solidarity are bought with the same linguistic currency! (Cameron, 1998). 


\subsection{Bureaucracy}

This is endemic in all professions and funding requires obsessive attention to form filling as well as risk and accountability.

In this era of risk assessment and financial accountability compulsive devotion to detail is a requirement. It is also exacerbated by the fact that the responsibility is dispersed on to front line clinical staff.

Weber's version of alienation was manifested in the concept of Rationalisation (Swidler, 1973). Much of the joy and satisfaction achieved by clinicians is to see improvements in the life of their clients; however they and their clients are often encased in a Weberian bureaucratic nightmare of the Iron cage of rationality (Barker, 1993).

This creates the occasion for great humour much of it based on the tension between control and lack of control. It is understandable under the remit of Doxa (Eagleton \& Bourdieu, 1992) that unskilled attempts to control, create sun controllability.

\section{Literature}

Tomei et al. (2011: p. 401) echoes a very common theme encapsulated in "Only the words we use when dealing with the topic has changed over the time: once it was Alienation now it is Burn-out”. The sentence is grammatically and semantically valid but includes within it ideological assumptions. In the constrained paradigm of psychology the author does not (and indeed does not need to) address the constitutive aspect of language. They also go on further to offer the solution, "it is necessary to define the goals of the company and the role each employee has".

Maslach (1993) revels in poignant abstractions such as emotional exhaustion; depersonalisation based on a person's negative perception of his or her recipients and reduced personal accomplishment that includes a person's negative self-evaluation in relation to his or her work performance. Like many the author concludes that "burnout is an individual stress experience" (p. 19) involving the persons attitude towards others and self. This is highly accurate and displays a great empathy with those who may suffer, but also represents merely a descriptive hollowness. Power, or indeed material considerations are precluded from the vocabulary.

Seeman (1959) wishes to "tie the historical interest in alienation to the modern empirical effort". However this is an ideologically loaded project if the nature of the empiricism is not unpacked and it signals a trajectory from its original materialist form to humanistic abstractions.

Sang in (Wu, 2008) also has noticed this and cites Fromm who in an attempt to develop Marx's Alienation theory rely in a reliance of humanitarian ideology.

Schaufeli et al. (1998) describe how Karger (1981) criticised the burnout literature first and foremost for privatising the nature of the problem.

Karger (1981) conducts a wide ranging study of the literature and assumptions made and parallel this is the problem of industrial alienation.

\section{Discussion}

The unquestioned updating and transitioning from the concept alienation to burnout represent a descent from a sacred materialist understanding to a profane and anaemic spiritual rhetoric; reinforcing what the latter claims to alleviate. This is due to continual waves of colonisation of the addiction/counselling field, firstly by medical then by unproblematised neo-liberal discourses. This descent is familiar to most professionals along with the recognition that the issue is better left unaddressed except through guerrilla tactics. Many AoD professionals enter the discipline with a passion born of family or personal experience having a desire to "pass the message on" (Wilson, 2015). Often this is seen as a spiritual vocation and inevitably the problem with clinicians is the overstepping of boundaries and taking on too much work, a routine challenge in clinical supervision. Part of professional practice training goes into warning against this issue. The phenomenon routinely is categorised under self-care and burnout discourses. Currently privileged is the rhetoric of burnout, a later version of alienation but a more acceptable term for overwork. The problem is that much of the overstepping of boundaries is a result of ever decreasing funding of the health services, not an individual pathology within the clinician, an inference facilitated by the burnout discourse.

In Aliention theory Marx described man (sic) as Homo-Faber. It was inherent and sacred in humans that their purpose on this earth was to labour in order to reproduce their fellow species. AoD clinicians reproduce indi- 
viduals into recovery from addiction and substance abuse. Although this work is often verbalised through spiritual discourses it is fundamentally a material project described aptly by the Salvation Army as of "soup soap and salvation" (Benge \& Benge, 2002). Interestingly the soup component under this regime is privileged over the salvation part, (or in it's updated from self-actualisation).

Alienation describes a situation when, "that which belongs together is broken apart" (Sahay, 2007). This occurs when the fruits of labour are robbed from those who produce. Moreover this is at once a material and spiritual exploitation. This can be understood at both macro and micro levels.

1) Macro level: The material and spiritual belong together (the dualism is false).

2) Micro level: for AoD clinicians their natural affinity is to help the distressed. However, what are known condescendingly as secondary stressors breaks them apart from their natural vocation.

The issue is that the doctrine of burnout and the suggested remedies has assumed a metaphysical abstract category. Clinicians collude in their utilisation but also in the knowledge that they do not work, in some cases making things worse. Paradoxically the recital of them is seen to be adequate, a ritual which consists of a neoliberal idolatry. Like many practices in the current field there is a marginalisation of cause/effect thinking. The cause of the burnout is peripheral, beyond a token mention, but the emphasis is on self-management of symptoms. This is all that is provided through the vacuous spirituality.

Marx inverted the idealism of Hegel, in his most quoted and misunderstood statement "religion is the opium of the people" (Marx, 1990). As such religion or in its degutted (Eagleton, 2014) form spirituality is according to this category key component in the facilitation of alienation.

Yet clinicians, like other professionals have developed their unwritten modes of resistance often magnificently through humour. Much of it cannot be addressed and perhaps that is just as well. But it also can be seen as a robust spirituality that recognises that humankind is at once spiritual due to its materiality and material due to its spirituality.

\section{References}

Armstrong, K. (1994). A History of God. Random House Digital, Inc.

Barker, J. R. (1993). Tightening the Iron Cage: Concertive Control in Self-Managing Teams. Administrative Science Quarterly, 38, 408-437. http://dx.doi.org/10.2307/2393374

Benge, J., \& Benge, G. (2002). William Booth: Soup, Soap, and Salvation. YWAM Publishing.

Cameron, D. (1998). The Feminist Critique of Language: A Reader. Psychology Press.

Clarkson, P. (1991). Groupimago and the Stages of Group Development. Transactional Analysis Journal, 21, 36-50.

Deutsch, C. J. (1984). Self-Reported Sources of Stress among Psychotherapists. Professional Psychology: Research and Practice, 15, 833. http://dx.doi.org/10.1037/0735-7028.15.6.833

Eagleton, T. (2014). Reason, Faith, \& Revolution: Reflections on the God Debate. Yale University Press.

Eagleton, T., \& Bourdieu, P. (1992). Doxa and Common Life. New Left Review, 191, 111.

Karger, H. J. (1981). Burnout as Alienation. Social Service Review, 55, 270-283. http://dx.doi.org/10.1086/643917

Marx, K. (1990). Religion, the Opium of the People. The World Treasury of Modern Religious Thought, 79-91.

Marx, K. (2012). Economic and Philosophic Manuscripts of 1844. Courier Corporation.

Maslach, C. (1993). Burnout: A Multidimensional Perspective. In W. Schaufeli, C. Maslach, \& T. Marek (Eds.), Professional Burnout: Recent Developments in Theory and Research. Series in Applied Psychology: Social Issues and Questions (pp. 19-32). Philadelphia, PA: Taylor \& Francis.

Morrissey, J., \& Tribe, R. (2001). Parallel Process in Supervision. Counselling Psychology Quarterly, 14, 103-110. http://dx.doi.org/10.1080/09515070126329

Sahay, G. R. (2007). Marxism and the Orient: A Reading of Marx. Borderlands, 6.

Schaufeli, W., \& Enzmann, D. (1998). The Burnout Companion to Study and Practice: A Critical Analysis. Boca Raton, FL: CRC Press.

Seeman, M. (1959). On The Meaning of Alienation. American Sociological Review, 24, 783-791.

http://dx.doi.org/10.2307/2088565

Swidler, A. (1973). The Concept of Rationality in the Work of Max Weber. Sociological Inquiry, 43, 35-42. http://dx.doi.org/10.1111/j.1475-682X.1973.tb01149.x

Tomei, G., Casale, T., Tomei, F., Nieto, H. A., Prenna, A., Schifano, M. P., \& Pimpinella, B. (2011). [Alienation to Burn- 
Out. Psyche and the Universe of Technology]. Giornaleitaliano di Medicina del Lavoroedergonomia, 34, 400-409.

Wilson, B. (2015). Alcoholics Anonymous: Big Book. AA World Services.

Wu, Y.-Z. (2008). Labor Alienation and Technique Alienation. Journal of Hengyang Normal University, 1, 006.

Žižek, S., \& Mortensen, A. (2014). Žižek’s Jokes: Did You Hear the one about Hegel and Negation? Cambridge: MIT Press.

\section{Appendix}

\begin{tabular}{|c|c|c|c|c|}
\hline No. & Suggestion & Assumptions & Solution & Responses \\
\hline 1 & Recognize and own the symptoms & Lack of knowledge & $\begin{array}{l}\text { Learn more about burnout, } \\
\text { thus reify its reality. }\end{array}$ & $\begin{array}{c}\text { I can own the symptoms but I } \\
\text { need to know how to solve the } \\
\text { problem }\end{array}$ \\
\hline 2 & Talk with someone about feelings & $\begin{array}{l}\text { Clinicians repress their } \\
\text { feelings }\end{array}$ & Be more open and honest & $\begin{array}{l}\text { I was caught being honest } \\
\text { about my feelings... }\end{array}$ \\
\hline 3 & Reschedule your work & $\begin{array}{l}\text { You have a problem with } \\
\text { timing }\end{array}$ & Prioritise & I have no time left in the day \\
\hline 4 & Cut down on your work & That this can be done & Reschedule & $\begin{array}{c}\text { There is a cap on new staff (he } \\
\text { said) }\end{array}$ \\
\hline 5 & Take a holiday & That this can be done & Take leave & $\begin{array}{l}\text { I've used up all my leave on } \\
\text { professional development }\end{array}$ \\
\hline 6 & Use relaxation or meditation & That this can be done & Relax & $\begin{array}{l}\text { I use these, the problem is not } \\
\text { solved }\end{array}$ \\
\hline 7 & Use positive self-talk & $\begin{array}{l}\text { Clinicians are irrationally } \\
\text { negative }\end{array}$ & Be more positive & $\begin{array}{l}\text { Humour, negativity, irony } \\
\text { works for me }\end{array}$ \\
\hline 8 & $\begin{array}{l}\text { Lower your expectations of yourself, } \\
\text { clients, colleagues and your employer }\end{array}$ & That this can be done & That this is possible & $\begin{array}{l}\text { My expectations of my employer } \\
\text { could not possibly be lower }\end{array}$ \\
\hline 9 & $\begin{array}{l}\text { Allow yourself to enjoy life and have a } \\
\text { sense of humour }\end{array}$ & $\begin{array}{l}\text { Clinicians have a poor sense } \\
\text { of balance }\end{array}$ & That this is possible & $\begin{array}{c}\text { I have a sense of humour and } \\
\text { irony }\end{array}$ \\
\hline 10 & $\begin{array}{l}\text { Use thought stopping to stop worrying } \\
\text { about clients when not at work }\end{array}$ & $\begin{array}{c}\text { Only primary stressors } \\
\text { concern clinicians after hours }\end{array}$ & Use your brain & $\begin{array}{l}\text { I practice that but I, } m \text { worrying } \\
\text { if I'll have a job next week }\end{array}$ \\
\hline 11 & $\begin{array}{l}\text { Use your religious or other belief } \\
\text { system for support }\end{array}$ & Your belief system is faulty & $\begin{array}{l}\text { Change your belief system } \\
\text { to suit the workplace }\end{array}$ & $\begin{array}{l}\text { There is nothing wrong with my } \\
\text { religious/ethical beliefs }\end{array}$ \\
\hline 12 & $\begin{array}{l}\text { Care for yourself as a person by doing } \\
\text { some nice things for yourself }\end{array}$ & $\begin{array}{l}\text { Clinicians are incapable of } \\
\text { self-care }\end{array}$ & $\begin{array}{l}\text { Use the mythologies of } \\
\text { solutions to burnout }\end{array}$ & $\begin{array}{c}\text { That what gets me into trouble } \\
\text { with my employer }\end{array}$ \\
\hline
\end{tabular}

